\title{
Amīrzāde-ye kāšì-hā, naqd-e še 'r-e mo'āṣer, Aḥmad Šāmlū. Tehrān, Morvārīd, 1384, 723 p. [Le prince des mosaïques, critique de la poésie contemporaine]
}

\section{Atéfé Tahaï}

\section{OpenEdition}

\section{Journals}

Édition électronique

URL : http://journals.openedition.org/abstractairanica/21801

DOI : 10.4000/abstractairanica. 21801

ISSN : 1961-960X

Éditeur :

CNRS (UMR 7528 Mondes iraniens et indiens), Éditions de l'IFRI

Édition imprimée

Date de publication : 15 mai 2007

ISSN : 0240-8910

\section{Référence électronique}

Atéfé Tahaï, « Amīrzāde-ye kāšī-hā, naqd-e še'r-e mo'āșer, Ahmad Šāmlū. Tehrān, Morvārīd, 1384, 723 p. [Le prince des mosaïques, critique de la poésie contemporaine] », Abstracta Iranica [En ligne], Volume 28 | 2007, document 381, mis en ligne le 18 septembre 2007, consulté le 25 septembre 2020. URL : http://journals.openedition.org/abstractairanica/21801; DOI : https://doi.org/10.4000/ abstractairanica. 21801

Ce document a été généré automatiquement le 25 septembre 2020.

Tous droits réservés 


\title{
Amìrzāde-ye kāšì-hā, naqd-e še $r$-e mo'āṣer, Aḥmad Šāmlū. Tehrān, Morvārīd, 1384, 723 p. [Le prince des mosaïques, critique de la poésie contemporaine]
}

\author{
Atéfé Tahaï
}

1 L'œuvre de Aḥmad Šāmlū (1925-2000) a déjà fait l'objet de plusieurs recherches: Critique sur l'œeuvre de Šāmlū (1973) par 'A. Dastġeyb; La poésie de notre temps, A. Šāmlū (1989) par M. Ḥoqūqī ; Voyage dans le brouillard (1995) par T. Pūrnāmdāriān. Prenant en compte ces recherches, cet ouvrage réunit et développe les sujets déjà présentés par Dastġeyb et Ḥoqūqī.

2 Le livre se compose d'une chronologie, d'une préface et de neuf chapitres d'étude dont le premier est consacré aux spécificités et au style de Šāmlū. Les huit chapitres suivants comprennent une analyse détaillée des poèmes ( $71 \%$ de l'ensemble des poèmes de Šāmlū) mais l'A. n'en profite pas pour établir une synthèse. Bien qu'il y ait parfois des remarques ou des informations intéressantes, nous sommes devant des données brutes. Ces huit chapitres, à l'exception de celui concernant les poèmes folkloriques, suivent la classification thématique des poèmes : poèmes sociaux, romances, élégies, ...

3 L'ouvrage se termine par un index des poèmes étudiés, avec une liste des sources utilisées par l'A. Ce qui surprend, c'est de ne pas y trouver la bibliographie de Šāmlū ! Cet ouvrage pourrait toutefois intéresser les étudiants de la littérature persane. 
INDEX

Thèmes : 11.1.2. Littérature persane moderne

\section{AUTEURS}

ATÉFÉ TAHAï

Téhéran 